\title{
PHYLOGENETIC RELATIONSHIPS WITHIN UVULARIA (COLCHICACEAE) BASED ON MORPHOLOGY
}

\author{
Department of Biology \\ Warren Wilson College \\ CPO 6074, PO Box 9000 \\ Asheville, NC 28815-9000 \\ 828-771-2018 \\ aboyd@warren-wilson.edu
}

AMY E. BOYD* and ISAIAH M. THALMAYER

\begin{abstract}
The five species of bellworts in the genus Uvularia are common woodland herbs endemic to eastern North America. Two previous studies conducted phylogenetic analyses of Uvularia based on $m a t \mathrm{~K}$ and $r b c \mathrm{~L}$ gene sequences. The objective of this study was to create a phylogeny for Uvularia based on 18 qualitative morphological characters and 14 quantitative characters. Two phylogenetic analyses were performed, one including all 32 characters and one excluding the 14 quantitative characters. Strict consensus trees from the two analyses had the same topology and were congruent with published molecular phylogenies, supporting two sections of the genus.
\end{abstract}

Key Words: Uvularia; morphological phylogenetics; quantitative characters; Colchicaceae.

\section{INTRODUCTION}

Uvularia L. (Colchicaceae) is a genus of woodland herbs comprising five species endemic to eastern North America, from Nova Scotia and Quebec southward to Florida and Texas (Soper 1953; Wilbur 1963; Utech \& Kawano 1999, 2003). All five species are understory perennials with bell-shaped flowers that bloom from April to mid-June (Kawano and Iltis 1964) and are stoloniferous, growing in dense clumps (McCall and Primack 1987). Uvularia grows in well-drained or mesic upland forests or in swampy alluvial bottomlands and rarely in xeric coniferous woodlands (Hayashi et al. 1998). Seeds are ant-dispersed in late summer (Whigham 1974).

Uvularia was divided into two genera based on morphological characteristics, Oakesia Watson (later renamed Oakesiella by Small 1913) comprising three sessile-leaved species (U. puberula, $U$. floridana and $U$. sessilifolia), and Uvularia, comprising two perfoliate species (U. grandiflora and U. perfoliata; Watson 1897). Wilbur (1963) later reunited all five species into Uvularia on the basis of morphological characteristics such as branching pattern and inflorescence structure, and still recognized the two groups as sections [Section Oakesiella (Small) Wilbur and Section Uvularia].

Two phylogenetic studies of Uvularia based upon molecular data (Shinwari 1988; Hayashi et al. 1998) used $\mathrm{rbcL}$ and matK sequence data. The results of both studies supported Uvularia as a monophyletic group as

\footnotetext{
* Author for correspondence.
}

well as Wilbur's (1963) division of Uvularia into two sections as described above.

We present here a phylogenetic study of Uvularia based upon morphological characters. The objectives of this study were (1) to analyze the morphology of the five species in Uvularia and construct a phylogeny based on shared morphological characteristics, and (2) to compare the morphological phylogeny to previous studies based on molecular data (Hayashi et al. 1998).

\section{METHODS}

Taxon sampling. All five species of Uvularia were included in the study. We selected Prosartes lanuginosa (Michx.) D. Don as our outgroup based on Hayashi et al. (1998). Herbarium specimens of $U$. puberula Michx., $U$. sessilifolia L., U. grandiflora Smith, and U. perfoliata L., and the outgroup, P. lanuginosa (Michx.) D. Don, were borrowed from the herbaria listed in the acknowledgments and below. Both fruiting and flowering specimens of all six species were obtained for evaluation of characters pertaining to both life stages.

Specimens examined: Uvularia floridana: FLAS: S. Daniel 8571, A. Gholson Jr. 11578, S.L. Orzell 3816159, D.B. Ward 38; TENN: R. Kral 26212, 57408.

Uvularia grandiflora: BOON: Carpenter 3967, T.R. Fisher 119, S. Hearn 39, B. Kallenbach 35, Love 4019, D. Morrison 9, S. Perry 12-607, T.P. Taylor; TENN: R. Boner 47719, E.M. Browne 4034, E.A. Burdo 28-343, T. Koyama 13081, P. Marx 34306, V.E. McNellus no \#, G.W. Ramsey 373. 
Table 1. Characters and character states used in the analysis of Uvularia. All multistate characters were treated as unordered. Consistency index (CI) and retention index (RI) are given for each character.

\begin{tabular}{|c|c|c|c|c|}
\hline & Character & Character States & $\mathrm{CI}$ & RI \\
\hline 1. & Leaf attachment & $0=$ sessile, $1=$ perfoliate & 1 & 1 \\
\hline 2. & Leaf margin & $0=$ ciliate, $1=$ entire, $2=$ papillose & 1 & 1 \\
\hline 3. & Leaf indumenta & $0=$ lanulose, $1=$ glabrous, $2=$ pubescent & 0.67 & 0 \\
\hline 4. & Leaf width & $0=\geq 14 \mathrm{~mm}, 1=<14 \mathrm{~mm}$ & 0.33 & 0 \\
\hline 5. & Leaf length & $0=\geq 54 \mathrm{~mm}, 1=<54 \mathrm{~mm}$ & 0.5 & 0.5 \\
\hline 6. & Stem cross-section & $0=$ terete $; 1=$ distally angled & 1 & 1 \\
\hline 7. & Stem pith & $0=$ hollow $; 1=$ solid & 1 & 1 \\
\hline 8. & Stem length & $0=\geq 600 \mathrm{~mm} ; 1=350-600 \mathrm{~mm} ; 2=<350 \mathrm{~mm}$ & 0.67 & 0 \\
\hline 9. & Internode length & $0=\geq 30 \mathrm{~mm} ; 1=<30 \mathrm{~mm}$ & 1 & 1 \\
\hline 10. & Number of nodes on sterile branch & $0=$ no sterile branch; $1=<6$ nodes; $2=\geq 6$ nodes & 0.5 & 0 \\
\hline 11. & Number of flowers per shoot & $0=2-25 ; 1=1-3 ; 2=1-2 ; 3=1$ & 1 & 1 \\
\hline 12. & Bract & $0=$ absent $; 1=$ present, perfoliate $; 2=$ present, sessile & 1 & 1 \\
\hline 13. & Pedicel length & $0=\geq 10 \mathrm{~mm} ; 1=<10 \mathrm{~mm}$ & 0.5 & 0.67 \\
\hline 14. & Tepal length & $0=<23 \mathrm{~mm} ; 1=\geq 23 \mathrm{~mm}$ & 0.5 & 0.67 \\
\hline 15. & Tepal width & $0=<4.75 \mathrm{~mm} ; 1=\geq 4.75 \mathrm{~mm}$ & 0.5 & 0.5 \\
\hline 16. & Stamen length & $0=<14.5 \mathrm{~mm} ; 1=\geq 14.5 \mathrm{~mm}$ & 1 & 1 \\
\hline 17. & Filament length & $0=<4.5 \mathrm{~mm} ; 1=\geq 4.5 \mathrm{~mm}$ & 1 & 1 \\
\hline 18. & Anther length & $0=<6 \mathrm{~mm} ; 1=6-9 \mathrm{~mm} ; 2=\geq 9 \mathrm{~mm}$ & 0.5 & 0 \\
\hline 19. & Length of connective protrusion on anther & $0=<0.5 \mathrm{~mm} ; 1=\geq 0.5 \mathrm{~mm}$ & 1 & 1 \\
\hline 20. & Location of stamen attachment & $0=$ receptacle $; 1=$ tepal & 1 & 1 \\
\hline 21. & Stigmatic lobe length & $0=<4.25 \mathrm{~mm} ; 1=\geq 4.25 \mathrm{~mm}$ & 0.5 & 0.5 \\
\hline 22. & Style length & $0=<10 \mathrm{~mm} ; 1=\geq 10 \mathrm{~mm}$ & 0.33 & 0.33 \\
\hline 23. & Length of stigmatic exertion beyond stamen & $0=<-1 \mathrm{~mm} ; 1=-1$ to $4 \mathrm{~mm} ; 2=\geq 4 \mathrm{~mm}$ & 0.67 & 0 \\
\hline 24. & Ovary attachment & $0=$ sessile $; 1=$ stipitate & 1 & 1 \\
\hline 25. & Ovary profile & $0=$ round; $1=$ ovate; $2=$ rhombic $($ apex acute) $3=$ obovoid & 1 & 1 \\
\hline 26. & Fruit shape & $0=$ round $; 1=$ obpyramidal; $2=$ ovate & 1 & 1 \\
\hline 27. & Fruit cross section & $0=$ entire; $1=$ lobed; $2=$ sharply angled & 1 & 1 \\
\hline 28. & Lobes of fruit & $0=$ nonbifid $; 1=$ bifid & 1 & 1 \\
\hline 29. & Fruit apex shape & $0=$ round $; 1=$ truncate $;=$ rostrate $3=$ acute & 1 & 1 \\
\hline 30. & Aril type & $0=$ basal; $1=$ crested $; 2=$ membranous & 1 & 1 \\
\hline 31. & Rhizome length & $0=\geq 10 \mathrm{~mm} ; 1=<10 \mathrm{~m}$ & 0.5 & 0.5 \\
\hline 32. & Anther attachment & $0=$ dorsifixed $; 1=$ linear & 1 & 1 \\
\hline
\end{tabular}

Uvularia perfoliata: BOON: L.W. Carpenter 3050, M. Hicks 8931, D.B. Pointdexter 05-256; TENN: J.G. Allawos 60, D. Dixon 2920, E. Edward 3098, D. Estes 08754, C.J. Hansen 2001-32, P. Kotter no \#, R. Kral 34252, D. Lashlee no \#, L. Lipps no \#, V.E. McNellus 93-408, B.T. Mounts no \#, H.L. Sherman 089.

Uvularia puberula: BOON: Carrigan 34-5200, M. Livengood 20-6503, W. Miller 3905, D.B. Pointdexter 81-17476, Roberson 79-3860, A. Rodgers 23, Dot Simpson 1975; TENN: P. DePriest 85, M.A. Feist 406. 2892, E.L. Green 1120, R.L. James 18904, L. R. Phillippe 30221, 33343, R.E. Shanks 15210, R.D. Thomas 33354, L.J. Uttal 6998; WWC: C. Blaine no \#, L. Laufer no \#, B. Sharp no \#.

Uvularia sessilifolia: BOON: R. Kral 34251, D.W. Woods 1795; TENN: D.E. Boufford 23324, J.M. Coleman 46331, D. Estes 01825, R. Kral 16401, 34393, 42385, V.E. McNellus 89-244, 90-13, P.A. Schmalzer 562, R.D. Thomas 70311, no \#, D.H. Webb 734, R.D. Thomas 70311; WWC: M. Heller no \#.

Prosartes lanuginosa: BOON: E. Croon 12-491, C.A. Flemming 17080, D.I. Glasco 12-669, E. Gillespie 16640, W. Hester 11-159, Hicks 8936; M. Monroe
15708, R.C. Patton 5015, D.B. Pointdexter 05-121, A. Rodgers 6873, R. Ruis 5017, Stanberry 112, T.P. Taylor 10-046.

Characters. Thirty-two morphological characters were selected (Table 1): 18 qualitative and 14 quantitative characters, based upon observation and from the literature (e.g., Wilbur 1963; Radford et al. 1968). All characters were analyzed in at least 15 specimens of each species, except $U$. floridana (6 specimens). All quantitative characters were measured with a digital caliper with repeatability to $0.01 \mathrm{~mm}$. These characters (characters 4 , $5,8,9,13-15,16-19$, and 21-23) were coded using break points established by visual inspection of ranges plotted for individual species. Selected character states were non-overlapping at the $95 \%$ confidence interval; taxa that were polymorphic were assigned multiple character states.

Data analysis. The character by taxon matrix (Table 2) was assembled using MacClade 4.08 software (Maddison and Maddison 2005). All character states for polymorphic taxa were entered, and polymorphic characters were treated as polymorphic in the phylogenetic analysis (corresponding to method \#6 for treating polymorphic 
Table 2. Distribution of character states among taxa. Characters are numbered as in Table 1. The presence of more than one character state indicates that taxa are polymorphic for that character.

\begin{tabular}{|c|c|c|c|c|c|c|c|c|c|c|c|c|c|c|c|c|}
\hline Taxon & 1 & 2 & 3 & 4 & 5 & 6 & 7 & 8 & 9 & 10 & 11 & 12 & 13 & 14 & 15 & 16 \\
\hline Uvularia puberula Michaux & 0 & 1 & $1 / 2$ & 1 & 0 & 1 & 1 & 2 & $0 / 1$ & 1 & 3 & 0 & $0 / 1$ & $0 / 1$ & $0 / 1$ & 0 \\
\hline U. sessilifolia $\mathrm{L}$. & 0 & 1 & 2 & $0 / 1$ & 0 & 1 & 1 & 2 & 1 & $1 / 2$ & 1 & 0 & $0 / 1$ & 0 & 0 & 0 \\
\hline U. floridana Chapman & 0 & 1 & 2 & 0 & 0 & 1 & 1 & 2 & 1 & $1 / 2$ & 1 & 2 & 1 & 1 & 0 & 0 \\
\hline U. perfoliata $\mathrm{L}$. & 1 & 2 & 2 & $0 / 1$ & $0 / 1$ & 0 & 0 & $1 / 2$ & $0 / 1$ & 1 & 2 & 1 & $0 / 1$ & $0 / 1$ & $0 / 1$ & 0 \\
\hline U. grandiflora Smith & 1 & 2 & $1 / 2$ & 0 & 1 & 0 & 0 & 1 & 1 & $1 / 2$ & 2 & 1 & 0 & 1 & 1 & 1 \\
\hline $\begin{array}{l}\text { Prosartes lanuginosa } \\
\text { (Michaux) D. Don }\end{array}$ & 0 & 0 & 0 & 0 & $0 / 1$ & 0 & 0 & 0 & 0 & 0 & 0 & 0 & 0 & 0 & 0 & 0 \\
\hline Taxon & 17 & 18 & 19 & 20 & 21 & 22 & 23 & 24 & 25 & 26 & 27 & 28 & 29 & 30 & 31 & 32 \\
\hline Uvularia puberula Michaux & 1 & $1 / 2$ & 0 & 0 & 1 & 0 & 1 & 0 & 1 & 2 & 2 & 0 & 2 & 1 & 1 & 1 \\
\hline U. sessilifolia $\mathrm{L}$. & 1 & 1 & 0 & 0 & 0 & $0 / 1$ & $1 / 2$ & 1 & 1 & 2 & 2 & 0 & 2 & 1 & 0 & 1 \\
\hline U. floridana Chapman & 1 & 1 & 0 & 0 & 0 & 0 & $1 / 2$ & 0 & 2 & 2 & 2 & 0 & 3 & 1 & 0 & 1 \\
\hline$U$. perfoliata $\mathrm{L}$. & 1 & $1 / 2$ & 1 & 1 & $0 / 1$ & $0 / 1$ & 1 & 0 & 1 & 1 & 1 & 1 & 1 & 2 & 1 & 1 \\
\hline U. grandiflora Smith & $0 / 1$ & 2 & $0 / 1$ & 0 & 1 & 1 & $0 / 1$ & 0 & 3 & 1 & 1 & 0 & 1 & 2 & 1 & 1 \\
\hline $\begin{array}{l}\text { Prosartes lanuginosa } \\
\text { (Michaux) D. Don }\end{array}$ & 0 & 0 & 0 & 0 & 0 & $0 / 1$ & 1 & 0 & 0 & 0 & 0 & 0 & 0 & 0 & 0 & 0 \\
\hline
\end{tabular}

characters in Kornet and Turner 1999). Maximum parsimony analyses and bootstrap analyses were performed in PAUP* 4.0b10 (Swofford 2003). All characters were unordered and equally weighted, and tree construction was conducted using an exhaustive search. Clade support was estimated using bootstrap analyses (Felsenstein 1985; Hillis and Bull 1993), with 1,000 bootstrap replicates, as well as decay indices generated via constraint trees. Consistency index, retention index, and rescaled consistency index were obtained from MacClade for each tree.

We initially performed two phylogenetic analyses: the first including all 32 characters, and the second restricted to the 18 qualitative characters. We performed this second analysis because the size of structures of the same species varied depending on the time of year and growth stage. In general, specimens of the same species collected later in the growing season had larger structures (such as leaves, flowers, and stem lengths) than specimens collected earlier in the growing season. Quantitative characters were eliminated in the second analysis for the purpose of minimizing this temporal variation within the same species.

To evaluate the phylogenetic utility of the various characters in the data set, we calculated consistency index (CI) and retention index (RI) for each character. We then repeated the phylogenetic analyses, reweighting the characters based upon these values, to determine if this would give us better phylogenetic resolution and/or better clade support.

In addition to the phylogenetic analysis, we also performed a principal components analysis on the quantitative character data using $\mathrm{JMP}^{\circledR}$ statistical analysis software (version 8), to examine the way in which variation in size of these characters may or may not distinguish different taxa from one another.

\section{RESULTS}

Parsimony analysis of the complete data set yielded six most-parsimonious trees of 45 steps $(\mathrm{CI}=0.96, \mathrm{RI}=$ $0.87, \mathrm{RC}=0.83$; Fig. 1). The strict consensus of these six trees is shown in Figure 1, with branches labeled with bootstrap values above 50\% and decay indices above 1 . Parsimony analysis of the qualitative character data yielded three most parsimonious trees of 30 steps $(\mathrm{CI}=0.97, \mathrm{RI}=0.93, \mathrm{RC}=0.90$; Fig. 2$)$. The strict consensus of these three trees is given in Figure 2, with branches labeled with bootstrap values above $50 \%$ and decay indices above 1 .

Both the qualitative data phylogeny and the complete data phylogeny contain a clade composed of $U$. grandiflora $+U$. perfoliata, supported by high bootstrap values of 96 in both. In addition, both phylogenies include a clade consisting of a polytomy of the remaining three species (U. puberula, U. sessilifolia, $U$. floridana), with bootstrap values of 51 (unsupported; we base our interpretation of bootstrap values upon Hillis and Bull 1993) in the complete data phylogeny and 69 (weak support) in the qualitative data phylogeny.

Character states supporting the monophyly of $U v u$ laria include lanulose leaf indumenta (character 3) and dorsifixed anther (character 32). Character states supporting the monophyly of Section Oakesiella include sessile leaves (character 1), papillose leaf margins (character 2), distally angled stems in cross section (character 6), and ovate, sharply-angled fruits (characters 26 and 27), and crested arils (character 30). Character states supporting the monophyly of Section Uvularia include perfoliate leaves (character 1), entire leaf margins (character 2), terete stems in cross section (character 6), solid stem pith (character 7), obpyramidal lobed fruits (characters 26 and 27), and membranous arils (character 30 ). Morphological synapomorphies are 


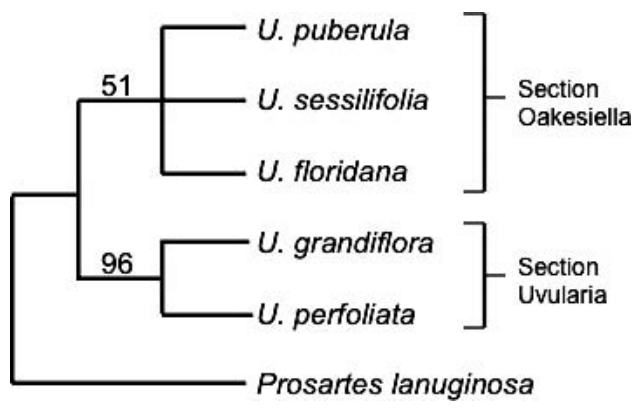

FIG. 1. Strict consensus of six most-parsimonious trees describing phylogenetic relationships within the genus Uvularia based on parsimony analysis of all 32 morphological characters (length $=46$, consistency index $(\mathrm{CI})=0.96$, retention index $(\mathrm{RI})=0.87$, rescaled consistency index $(\mathrm{RC})=0.83)$. Bootstrap support values $(\%)$ greater than or equal to 50 are shown above branches. Decay indices were all $=1$ (not shown).

mapped upon the consensus tree in Figure 3. CI and RI for individual characters (Table 1) show that the most phylogenetically informative characters include those named above.

When the phylogenetic analyses were repeated with characters reweighted based upon CI and RI values, resulting tree topologies were the same as the initial analyses, but in the analysis of qualitative data, bootstrap values for the sessile-leaved clade (Section Oakesiella) were much stronger ( 85 using CI for weighting; 84 using RI for weighting; Fig. 4).

Principal components analysis (PCA) of the quantitative character data clearly separated $U$. grandiflora from the other Uvularia species in the first two dimensions, but all other species overlap substantially (Fig. 5). The first principal component (PC1), accounting for $37 \%$ of the variation in the data set, has eight eigenvectors between 0.28 and 0.40 , representing size of

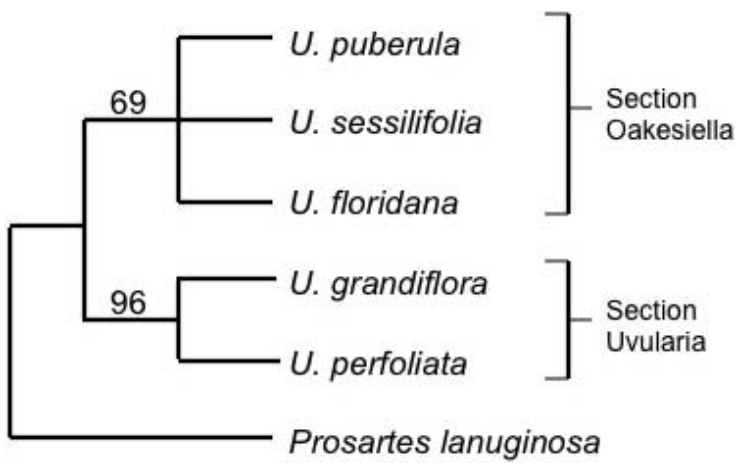

FIG. 2. Strict consensus of three most-parsimonious trees describing phylogenetic relationships within the genus Uvularia based upon parsimony analysis of 18 qualitative morphological characters (length $=30$, consistency index $(\mathrm{CI})=0.97$, retention index $(\mathrm{RI})=0.93$, rescaled consistency index $(\mathrm{RC})=0.90)$. Bootstrap support values $(\%)$ greater than or equal to 50 are shown above branches. Decay indices were all $=1$ (not shown).

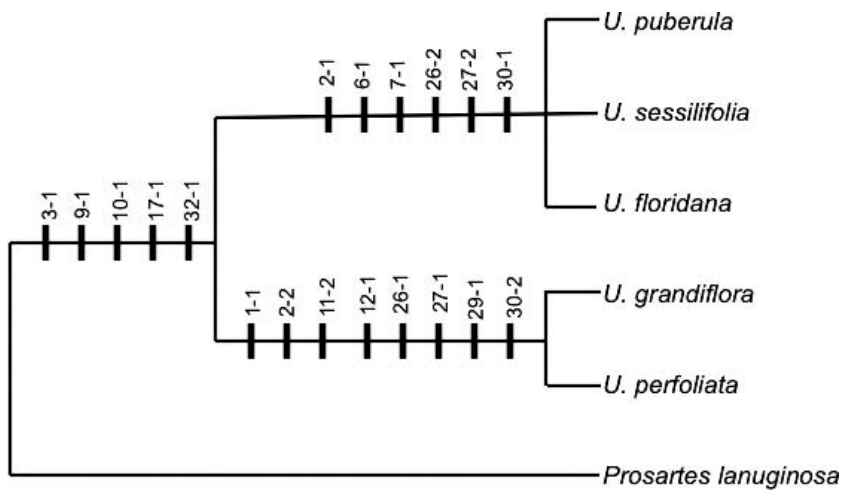

FIG. 3. Strict consensus of three most-parsimonious trees obtained from analysis of qualitative morphological characters in the genus Uvularia with state changes mapped for significant characters (see discussion). Numbers for characters and character states are as listed in Table 1.

floral structures and stem lengths/internode lengths. All of these are positive except for filament length, which appears to vary inversely with anther length, as well as stem length and internode length. PC1 has low eigenvectors for characters involving leaf size and style length. Therefore, PC1 generally represents floral size (except style length). U. grandiflora has higher values for PC1 than U. sessilifolia and U. floridana, but overlaps with $U$. puberula and $U$. perfoliata on this axis. PC1 also distinguishes $U$. puberula from $U$. sessilifolia, with $U$. puberula having higher values for $\mathrm{PCl}$; this is notable because these two taxa are sister taxa on the phylogeny and have many similarities otherwise.

The second principal component (PC2) accounts for an additional $28 \%$ of the variation in the data. PC2 has highest eigenvectors for leaf size measurements, stem length, and a few measurements of floral size such as stamen length and tepal length, all of which are positive. Lowest eigenvectors for PC2 include style lobe length, style exertion, and anther length. Therefore, PC2 represents another indicator of plant size with emphasis on leaf size, stem length, and corolla length. PC2 separates $U$. grandiflora even more strongly from the other taxa than does PC1, while the other taxa overlap substantially on this axis.

Principal Component 3 (PC3) accounts for an additional $10 \%$ of the variation, and has highest eigenvectors for style length and style exertion. However, this axis when graphed (not shown) does not separate the species from one another and therefore is not a useful variable for us here.

\section{DISCUSSION}

Results of both phylogenetic analyses support $U$. grandiflora and $U$. perfoliata as sister taxa with several synapomorphies including: perfoliate leaves (character 1); entire leaf margins (character 2); obpyramidal, lobed 
Table 3. Eigenvectors and eigenvalues for the first three principal components from analysis of quantitative characters, together explaining $75 \%$ of the variation in the data set. Characters are listed in descending order of PC1 loadings.

\begin{tabular}{lrrr}
\hline \multicolumn{1}{c}{ Character } & PC1 & PC2 & PC3 \\
\hline Anther length & 0.4008 & 0.1568 & 0.0149 \\
Style lobe length & 0.3653 & 0.1038 & 0.1590 \\
Filament length & -0.3417 & 0.2463 & -0.0660 \\
Tepal width & 0.3325 & 0.2451 & -0.0213 \\
Stem length & -0.3200 & 0.3143 & -0.0351 \\
Length of connective protrusion on anther & 0.2963 & -0.0745 & -0.1317 \\
Tepal length & 0.2948 & 0.2969 & -0.1867 \\
Internode length & -0.2751 & 0.2080 & -0.0179 \\
Stamen length & 0.2443 & -0.0965 \\
Leaf width & -0.2265 & -0.0112 \\
Leaf length & -0.0801 & 0.3303 & 0.6616 \\
Length of style exertion past stamen & -0.0683 & 0.4125 & 0.3209 \\
Pedicel length & -0.0474 & -0.1789 & 0.5375 \\
Style length & 0.0390 & 0.2918 & 1.43 \\
Eigenvalues & 5.19 & 0.2583 & 10.20 \\
\% variance explained & 37.09 & 3.90 & 27.85 \\
\hline
\end{tabular}

fruit shape (characters 26 and 27); and membranous aril (character 30). The close relationship between these two species has also been supported by molecular data (Shinwari 1994; Hayashi 1998) and was recognized in early morphological studies as well (Wilbur 1963). This concordance of data from various sources leaves little doubt of this systematic relationship. These two taxa, in fact, are difficult to distinguish in the field. However, there are a few distinguishing characteristics, including some that were used in our analysis: stamen attachment location (on the receptacle in $U$. perfoliata; on the tepals in $U$. grandiflora), ovary profile shape (ovate in $U$. perfoliata; obovoid in $U$. grandiflora), and fruit lobe structure (bifid in $U$. perfoliata; non-bifid in $U$. grandiflora).

Both complete and qualitative data phylogenies show a polytomy of the remaining three species (U. puberula, $U$. sessilifolia, and $U$. floridana). A clade comprising these species was found in molecular studies (Shinwari

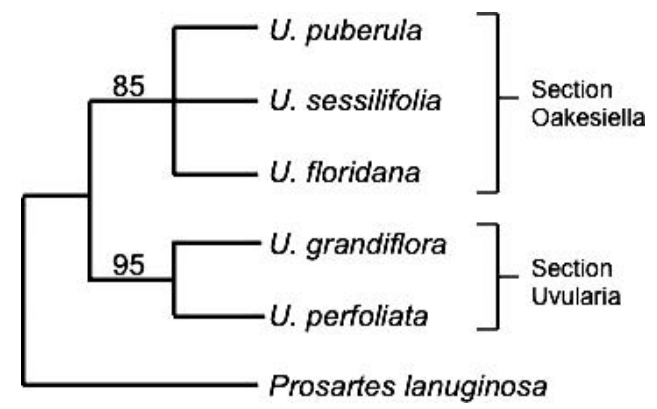

FIG. 4. Strict consensus of three most-parsimonious trees obtained from analysis of qualitative morphological characters in the genus Uvularia, with characters weighted according to consistency indices (length $=31$, consistency index $(\mathrm{CI})=0.98$, retention index $(\mathrm{RI})=$ $0.96)$. Bootstrap support values (\%) greater than or equal to 50 are shown above branches. Decay indices were all $=1$ (not shown). Weighting characters according to retention indices resulted in identical topology and comparable support.
1994; Hayashi 1998), and Hayashi (1998) showed better resolution within the clade with $U$. sessilifolia and $U$. floridana as sister taxa, and U. puberula as their basal group.

The division of the genus into distinct clades matches Wilbur's (1963) delineation of two sections within the genus, section Uvularia (U. grandiflora and U. perfoliata) and section Oakesiella (including the remaining three species). These sections have also been supported by molecular studies of the genus (Shinwari 1994; Hayashi 1998). The complete data and qualitative data analyses yielded identical phylogenies, although bootstrap values supporting the $U$. puberula $+U$. sessilifolia $+U$. floridana clade differed. This suggests that morphological structure size may not have been a confounding variable in determining relatedness between species as initially suspected. However, the fact that the U. puberula $+U$. sessilifolia $+U$. floridana clade, a clade strongly supported by molecular studies (Shinwari 1994; Hayashi 1998), is

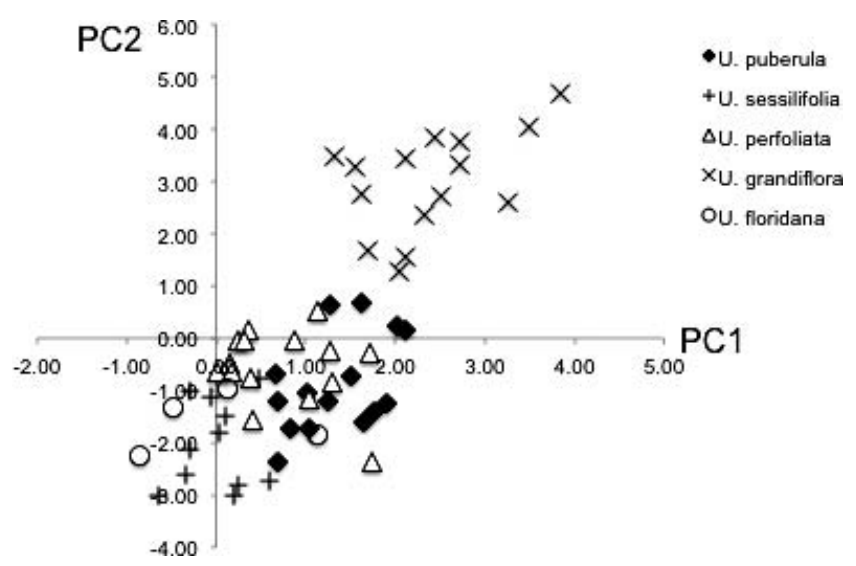

FIG. 5. First two principal components (PC1 and PC2) from PCA analysis of quantitative character data. Symbols indicate species of Uvularia. 
supported by a bootstrap value of 69 (weak support) in the qualitative data phylogeny and is not supported by a bootstrap value of 51 in the complete data phylogeny suggest that varying structure size may affect statistical analysis of phylogeny accuracy. In addition, when characters were weighted according to their phylogenetic usefulness (using CI and RI values), support for this clade became quite strong, with a bootstrap value of 85 .

Our observations suggest that the size of structures does vary between specimens of the same species of Uvularia depending on the time of year they were collected. Principal components analysis also demonstrated that the quantitative characters in general failed to separate the species into distinct groups, and only distinguished between $U$. grandiflora and the other four species. For these reasons, and because of congruence with molecular studies and higher bootstrap values, we place more confidence in the relationships delineated by the qualitative data phylogeny in Figure 4.

This phylogenetic analysis of the morphology of the five species in Uvularia produced a hypothesis of relatedness supporting phylogenies based on molecular data (Shinwari 1994; Hayashi 1998). Analyses of morphology indicate two clades within the genus: $U$. grandiflora $+U$. perfoliata and $U$. puberula $+U$. sessilifolia $+U$. floridana. These two clades match the division of Uvularia into two sections proposed by Wilbur (1963).

Acknowledgments: This research was supported by grants from the North Carolina Academy of Sciences and Warren Wilson College. Gratitude is given to the curators of the herbaria at Appalachian State University (BOON), University of Tennessee, Knoxville (TENN), the University of Florida, Gainesville (FLAS), and Warren Wilson College (WWC), who loaned Uvularia specimens crucial to completing this study.

\section{LITERATURE CITED}

BAKER, R. H., X. YU, AND R. DESALLE. 1998. Assessing the relative contribution of molecular and morphological characters in simultaneous analysis trees. Molecular Phylogenetics and Evolution 9(3):427-436.

FELSENSTEIN, J. 1985. Confidence limits on phylogenies: an approach using the bootstrap. Evolution 39(4):783-791.

HAYASHIK., S. YOSHIDA, H. KATO, F. H. UTECH, F. D. WHIGHAM, AND S. KAWANO. 1998. Molecular systematics of the genus Uvularia and selected Liliales based upon matK and $r b c L$ gene sequence data. Plant Species Biology 13(23):129-146.

HILLIS, D. M., AND J. J. BULL. 1993. An empirical test of bootstrapping as a method for assessing confidence in phylogenetic analysis. Systematic Biology 42(2):182-192.

JENNER, R. A. 2004. Accepting partnership by submission? Morphological phylogenetics in a molecular millenium. Systematic Biology 53(2):333-342.

JMP ${ }^{\circledR}$, Version 8. 1989-2007. SAS Institute, Inc., Cary, NC.

KAWANO, S., AND H. H. ILTIS. 1964. Cytotaxonomic and geographic notes on Uvularia (Liliaceae). Bull. Torrey Bot. Club 91(1):13-23.

KORNET, D. J., AND H. TURNER. 1999. Coding polymorphism for phylogeny reconstruction. Systematic Biology 48(2):365-379.

MADDISON, D. R., AND W. P. MADDISON. 2005. MacClade 4: Analysis of Phylogeny and Character Evolution. Version 4.08a. http://macclade.org

MCCALL, C., AND R. B. PRIMACK. 1987. Resources limit the fecundity of three woodland herbs. Oecologia 71(3):431-435.

NIXON, K. C., AND J. M. CARPENTER. 1993. On outgroups. Cladistics 9(4):413-426.

PATTERSON, C., D. M. WILLLIAMS, AND C. J. HUMPHRIES. 1993. Congruence between molecular and morphological phylogenies. Annual Review of Ecology and Systematics 24:153-188.

RADFORD, A. E., H. E. AHLES, AND C. R. BELL. 1968. Manual of the Vascular Flora of the Carolinas. The University of North Carolina Press.

SHINWARI, Z. K., R. TERAUCHI, F. H. UTECH, AND S. KAWANO. 1994. Recognition of the New World Disporum section Prosartes as Prosartes (Liliaceae) based on the sequence data of the rbcL gene. Taxon 43(3):353-366.

SMALL, J. K. 1913. Flora of the Southeastern United Sates. 2nd ed. Published by the author, Bronx, New York.

SOPER, J. H. 1952. Phytogeographic studies in Ontario I. The genus Uvularia in southern Ontario. Rhodora 54:58-67.

SWOFFORD, D. L. 2003. PAUP*. Phylogenetic Analysis Using Parsimony (*and Other Methods). Version 4. Sinauer Associates, Sunderland, Massachusetts.

UTECH, F. H., AND S. KAWANO. 1999. Uvularia. In: Flora of North America Editorial Committee. Flora of North America, North of Mexico. Vol. 22. Oxford University Press, New York.

UTECH, F. H., AND S. KAWANO. 2003. Uvularia. In: Flora of North America Editorial Committee (eds.), Flora of North America, Magnoliophyta: Liliidae: Liliales and Orchidales, 26:147-150, Oxford University Press, New York.

WATSON, S. 1879. A revision of the North American Liliaceae. Proceedings of the American Academy of Arts and Sciences $14: 213-288$.

WILBUR, R. L. 1963. A revision of the North American genus Uvularia (Liliaceae). Rhodora 65(762):158-188.

WHIGHAM, D. F. 1974. An ecological life history study of Uvularia perfoliata L. American Midland Naturalist 91(2):343-359.

WORTLEY, A. H., AND R. W. SCOTLAND. 2006. Determining the potential utility of datasets for phylogeny reconstruction. Taxon 55(2):431-442. 